\title{
Pengaruh Disiplin Kerja, Motivasi Dan Gaya Kepemimpinan Terhadap Kinerja Karyawan pada PT PLN (PERSERO) Unit Pelaksana Proyek Pembangkit dan Jaringan Sulawesi Selatan
}

\author{
${ }^{1}$ Annisa Awaliyah Ridwan, ${ }^{2}$ Anwar \\ Universitas Negeri Makassar, Kota Makassar, Indonesia

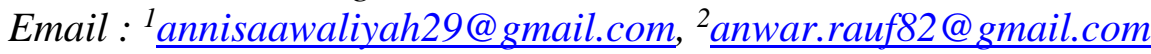

(Diterima: September 2021; Direvisi: Oktober 2021; Dipublikasikan: Januari 2022)

\begin{abstract}
ABSTRAK
Penelitian ini bertujuan untuk mengetahui bagaimana pengaruh Disiplin Kerja, Motivasi dan Gaya Kepemimpinan terhadap Kinerja Pegawai. Jumlah sampel yang digunakan sebanyak 36 Karyawan PT. PLN ULP Sulawesi Selatan. Pengumpulan data dilakukan dengan menggunakan metode wawancara, Observasi dan angket. Teknis analisi data yang digunakan adalah analisi regresi linier berganda dengan menggunkan Statistical Product and Servise Solution (SPSS). Hasil Penelitian ini menunjukkan Disiplin Kerja (X1) secara parsial memberikan pengaruh positif dan signifikan terhadap Kinerja Karyawan. Motivasi (X2) secara parsial memberikan pengaruh positif namun tidak signifikan terhadap Kinerja Karyawan. Gaya Kepemimpinan (X3) secara parsial memberikan pengaruh positif dan signifikan terhadap Kinerja Karyawan.
\end{abstract}

Kata Kunci: Disiplin Kerja, Motivasi, Gaya Kepemimpinan, Kinerja 


\section{PENDAHULUAN}

Sumber daya manusia merupakan bagian penting dalam organisasi maupun perusahaan. Keberhasilan suatu organisasi sangat dipengaruhi oleh kinerja individu karyawannya. Setiap organisasi maupun perusahaan akan selalu berusaha untuk meningkatkan kinerja karyawan, dengan harapan apa yang menjadi tujuan perusahaan akan tercapai. Menurut Setiyawan (2006) kinerja karyawan merupakan hasil atau prestasi kerja karyawan yang dinilai dari segi kualitas maupun kuantitas berdasarkan standar kerja yang ditentukan oleh pihak organisasi. Kinerja yang baik adalah kinerja yang optimal, yaitu kinerja yang sesuai standar organisasi dan mendukung tercapainya tujuan organisasi.

Salah satu hal yang mempengaruhi kinerja karyawan adalah disiplin. Disipin merupakan sebuah titik awal dari segala kesuksesan dalam rangka mencapai tujuan sebuah organisasi. Apabila tidak adanya penerapan disiplin kerja yang baik akan sulit bagi perusahaan untuk mencapai hasil yang optimal Hasibuan (2014:193). Penerapan disiplin dalam sebuah organisasi bertujuan agar semua karyawan yang ada dalam perusahaan tersebut bersedia mematuhi dan menaati setiap tata tertib yang berlaku.

Menurut Siagian (2013) disiplin merupakan bentuk pelatihan yang berusaha memperbaiki dan membentuk pengetahuan, sikap dan perilaku karyawan sehingga para karyawan secara sukarela berusaha bekerja secara kooperatif dengan karyawan yang lain serta meningkatkan prestasi kerjanya.
Karyawan yang kurang disiplin akan sulit melakukan produktivitas dan akan tidak mungkin untuk merealisasikan pencapaian tujuan yang diterapkan perusahaan sebelumnya. Begitupun yang terjadi pada karyawan pada PT. PLN (Persero) Unit Pelaksana Proyek Pembangkit dan Jaringan Sulawesi Selatan.

Karyawan yang memiliki motivasi tinggi serta disiplin yang baik hanya di dapat dengan penerapan konsep dan teknik manajemen sumber daya manusia yang tepat. Oleh karena itu, dibutuhkan juga seorang pemimpin yang baik harus berusaha agar para bawahannya mempunyai disiplin yang baik dan harus memberikan motivasi dalam menjalankan disiplin yang baik dalam suatu organisasi. Sehingga diperlukan gaya kepemimpinan dalam meningkatkan kinerja karyawan pada PT. PLN (Persero) Unit Pelaksana Proyek Pembangkit dan Jaringan Sulawesi Selatan. Kepemimpinan adalah kemampuan untuk memengaruhi suatu kelompok menuju pencapaian sebuah visi atas tujuan yang ditetapkan Robbins (2015).

Menurut Mulyadi (2011:42) gaya kepemimpinan adalah perilaku dan strategis, sebagai hasil kombinasi dan falsafah, keterampilan, sifat, sikap yang sering diterapkan seorang pemimpin ketika ia mencoba mempengaruhi kinerja bawahannya. Gaya kepemimpinan yang diterapkan pada PT. PLN (Persero) Unit Pelaksana Proyek Pembangkit dan Jaringan Sulawesi Selatan dapat dikatakan belum bisa mengoptimalkan kinerja karyawannya karena dilihat dari 
tingkat kehadiran dan ketepatan waktu dalam bekerja. Hal ini disebabkan oleh kurangnya efek hubungan pemimpin dengan karyawan, sehingga kominikasi antara karyawan dan pemimpin sangat kurang, dimana efek tersebut menimbulkan rasa kurangnya kepercayaan, kekaguman, kesetiaan terhadap pemimpin sehingga mereka tidak termotivasi untuk melakukan hal-hal yang lebih baik.

Penelitian ini bertujuan untuk mengetahui bagaimana pengaruh disiplin kerja, motivasi dan gaya kepemimpinan terhadap kinerja karyawan PT. PLN (Persero) Unit Pelaksana Proyek Pembangkit dan Jaringan Sulawesi Selatan.

\section{TINJAUAN PUSTAKA}

\section{Disiplin Kerja}

Kedisiplinan merupakan fungsi operasional manajemen sumber daya manusia yang terpenting karena semakin baik disiplin kerja karyawan, semakin baik kinerja yang dapat dicapai. Tanpa disiplin yang baik, sulit bagi organisasi untuk mencapai hasil yang optimal. Kedisiplinan merupakan faktor utama yang diperlukan sebagai alat peringatan terhadap karyawan yang tidak mau berubah sifat dan perilakunya. Sehingga seorang karyawan dikatakan memiliki disiplin yang kurang baik jika karyawan tersebut memiliki rasa tanggung jawab terhadap tugas yang diberikan kepadanya (Ghalih, 2013:3).

Menurut

Hasibuan

(2014:193) kedisiplinan adalah kesadaran dan kesedian seseorang mentaati semua peraturan perusahaan dan norma-norma sosial yang berlaku. Kesadaran adalah sikap seseorang yang secara sukarela mentaati semua peraturan dan sadar akan tugas dan tanggung jawabnya. Kesediaan adalah suatu sikap, tingkah laku, dan perbuatan seseorang yang sesuai dengan peraturan perusahaan baik yang tertulis maupun tidak tertulis.

2. Motivasi

Usman

(2014:276)

mengatakan motivasi merupakan kegiatan yang terdapat pada seseorang individu yang merangsangnya untuk melakukan tindakan-tindakan atau sesuatu yang menjadi dasar atau alasan seseorang berperilaku. Menurut Afandi (2016) motivasi adalah keinginan yang timbul dari dalam diri seseorang atau individual karena terinspirasi, tersemangati, dan terdorong untuk melakukan aktivitas dengan keikhlasan, senang hati dan sungguh-sungguh sehingga hasil dari aktivitas yang dilakukan mendapat hasil yang baik dan berkualitas.

Nawawi

(2011:351)

motivasi merupakan suatu kondisi yang mendorong atau menjadi sebab seseorang melakukan suatu perbuatan/kegiatan yang berlangsung secara sadar. Menurut Rivai (2014) motivasi adalah serangkaian sikap dan nilai-nilai yang mempengaruhi individu untuk mencapai hal yang spesifik sesuai dengan tujuan individu.

\section{Gaya Kepemimpinan}

Menurut Moeheriono (2012:380) kepemimpinan berasal dari kata pimpin yang memuat dua hal pokok, yaitu pemimpin sebagai subjek dan yang dipimpin sebagai objek. Kata pemimpin 
mengandung pengertian mengarahkan, mengendalikan, membina, atau mengatur, menuntun, dan juga menunjukkan ataupu mempengaruhi. Dan menurut Hasibuan (2014:170) kepemimpinan adalah cara seorang pemimpin mempengaruhi perilaku bawahan, agar mau bekerja sama dan bekerja secara produktif untuk mencapai tujuan organisasi.

\section{Kinerja Pegawai}

Torang, mengindentifikasian kinerja adalah kuantitas atau kualitas hasil kerja indvidu atau sekelompok di dalam organisasi dalam melaksanakan tugas pokok dan fungsi yang berpedoman pada norma, standar operasional prosedur kriteria dan ukuran yang telah ditetapkan atau yang berlaku dalam organisasi. Sedangkan menurut Riani (2013:61) Job Performance adalah tingkat produktifitas seorang karyawan, relatif pada rekan kerjanya, pada beberapa hasil dan perilaku yang terkait tugas.

Menurut Fahmi (2013:2) kinerja adalah hasil yang diperoleh suatu organisasi baik organisasi tersebut bersifat profit oriented dan non profit oriented yang dihasilkan selama satu periode waktu.

\section{Hipotesis}

Berdasarkan uraian yang telah dijelaskan sebelumnya maka hipotesis dalam penelitian ini adalah: H1 : Disiplin Kerja berpengaruh positif dan signifikan terhadap Kinerja Karyawan pada PT. PLN (Persero) Unit Pelaksana Proyek Pembangkit dan
Jaringan Sulawesi Selatan.

H2 : Gaya Kepemimpinan berpengaruh positif dan signifikan terhadap Kinerja Karyawan pada PT. PLN (Persero) Unit Pelaksana Proyek Pembangkit dan Jaringan Sulawesi Selatan.

H3 : Motivasi berpengaruh positif dan signifikan terhadap Kinerja Karyawan pada PT. PLN (Persero) Unit Pelaksana Proyek Pembangkit dan Jaringan Sulawesi Selatan.

H4 : Displin Kerja, Motivasi dan Gaya Kepemimpinan berpengaruh positif dan signifikan terhadap Kinerja Karyawan pada PT. PLN (Persero) Unit Pelaksana Proyek Pembangkit dan Jaringan Sulawesi Selatan.

\section{METODE PENELITIAN}

Penelitian ini dilakukan pada PT. PLN (Persero) Unit Pelaksana Proyek Pembangkit dan Jaringan, Sulawesi Selatan.

\section{Populasi dan Sampel}

Dalam penelitian ini yang menjadi populasi adalah seluruh karyawan di PT. PLN (Persero) Unit Pelaksana Proyek Pembangkit dan Jaringan Sulawesi Selatan sejumlah 36 orang dan penentuan sampel dalam penelitian ini menggunakan teknik sampling yaitu sampling jenuh adalah penentuan sampel pada semua anggota dalam satu kelompok atau populasi, sampling jenuh adalah teknik penentuan sampel bila semua anggota populasi dugunakan sebagai sampel. Istilah lain sampel jenuh adalah sensus, dimana semua 
anggota populasi dijadikan sampel.

\section{Teknik Pengumpulan Data}

Teknik pengumpulan data pada penelitian ini dilakukan dengan cara sebagai berikut:

1) Kuisioner, merupakan teknik pengumpulan data yang dilakukan dengan cara memberi seperangkat pertanyaan kepada responden untuk dijawab.

2) Observasi, sebagai teknik pengumpulan data mempunyai ciri yang spesifik bila dibandingkan dengan teknik lain.

\section{Teknik Analisis Data}

1) Uji Asumsi Klasik

Uji asumsi klasik dilakukan untuk mengetahui apakah model regresi yang dibuat dapat digunakan sebagai alat prediksi yang baik. Uji asumsi klasik yang akan dilakukan uji multikilonearitas, uji heteroskedastisitas, dan uji normalitas.
2) Analisis Regresi Linear Berganda

Analisis regresi linear berganda merupakan teknik analisis data yang digunakan dalam menganalisis pengaruh variabel bebas terhadap variabel terikat,

dimana:

$$
\begin{gathered}
\mathrm{Y}=\mathrm{a}+\beta 1 \mathrm{X} 1+\beta 2 \mathrm{X} 2+\beta 3 \mathrm{X} 3 \\
+\mathrm{e}
\end{gathered}
$$

Dimana:

$$
\begin{aligned}
\mathrm{Y} & =\text { Kinerja Karyawan } \\
\mathrm{a} & =\text { Konstanta } \\
\beta 1, \beta 2= & \text { Koefisien variabel } \\
& \text { independen } \\
\mathrm{X} 1 & =\text { Disiplin Kerja } \\
\mathrm{X} 2 & =\text { Motivasi } \\
\mathrm{X} 3 & =\text { Gaya Kepemimpinan } \\
\mathrm{e} & =\text { Nilai Residual }
\end{aligned}
$$

\begin{tabular}{|c|c|c|c|c|c|}
\hline \multirow{2}{*}{ Model } & \multicolumn{2}{|c|}{ Unstandardized Coefficients } & \multirow{2}{*}{$\begin{array}{c}\text { Standard } \\
\text { ized } \\
\text { Coeffici } \\
\text { ents } \\
\text { Beta }\end{array}$} & \multirow[b]{2}{*}{$\mathrm{t}$} & \multirow[b]{2}{*}{ Sig. } \\
\hline & B & Std. Error & & & \\
\hline $1 \quad$ (Constant) & $-12,464$ & 7,723 & & $-1,614$ & ,116 \\
\hline Disiplin Kerja & ,993 & ,316 & ,449 & 3,142 &, 004 \\
\hline Motivasi & 083 &, 133 & ,071 & ,626 & ,536 \\
\hline $\begin{array}{l}\text { Gaya } \\
\text { Kepemimpinan }\end{array}$ &, 537 &, 192 & ,400 & 2,797 & 009 \\
\hline
\end{tabular}

\section{HASIL PENELITIAN}

Berdasarkan analisis data yang menggunakan perhitungan regresi berganda dengan program SPSS (Statistical for product and servise solution) versi 23 , maka didapatkan hasil sebagai berikut :

Coefficients $^{\mathrm{a}}$

a. Dependent Variable: Kinerja

Persamaan regresi linier berganda tersebut adalah :

$Y=-12,464+0,993 X 1+0,083 X 2+$ $0,537 \times 3$ a. Nilai konstanta sebesar $-12,464$ menyatakan bahwa jika tidak ada variabel bebas (Disiplin Kerja, Motivasi dan Gaya Kepemimpinan) maka kinerja tetap menghasilkan nilai 
sebesar -12,464 atau dengan kata lain. Jika variabel bebas sama dengan 0 maka kinerja tetap menghasilkan $-12,464$.

b. Nilai koefisiensi regresi X1 sebesar 0,993 menyatakan bahwa setiap kenaikan 1 tingkat nilai X1 (disiplin kerja) akan mengakibatkan kinerja bertambah sebesar 0,993 dengan anggapan variabel bebas lain tidak mempengaruhi atau $=0$.

c. Nilai koefisiensi regresi X2 sebesar 0,083 menyatakan bahwa setiap kenaikan 1 tingkat nilai X2 (motivasi) akan mengakibatkan kinerja bertambah sebesar 0,083 dengan anggapan variabel bebas lain tidak mempengaruhi atau $=0$.

d. Nilai koefisiensi regresi X3 sebesar 0,537 menyatakan bahwa setiap kenaikan 1 tingkat nilai X3 (Gaya Kepemimpinan) akan mengakibatkan kinerja bertambah sebesar 0,537 dengan anggapan variabel bebas lain tidak mempengaruhi atau $=0$.

\section{Pengaruh Disiplin Kerja (X1)} Terhadap Kinerja (Y)

Disiplin adalah sikap atau kerelaan seseorang untuk mentaati dan mematuhi peraturan yang ada atau berlaku disekitarnya. Karyawan yang disiplin akan memudahkan perusahaan mencapai tujuannya, sedangkan kedisiplinan karyawan kurang baik maka akan menjadi penghalang perusahaan untuk mencapai tujuannya.

Berdasarkan hasil analisis regresi dan uji hipotesis yang menunjukkan bahwa variabel disiplin kerja membawa pengaruh yang positif dan signifikan terhadap kinerja pada PT. PLN (Persero) UP3J Sulawesi Selatan. Variabel ini juga yang memiliki pengaruh paling tinggi diantara variabel lainnya.

Berdasarkan hasil jawaban responden dapat diketahui bahwa jawaban responden dengan skor total paling tinggi pada kuesioner disiplin kerja (X1) adalah penyataan nomor 5 dengan indeks sebesar 90,56 \% dan nomor 6 dengan indeks yang sama. Pernyataan ini adalah berkaitan dengan indikator taat terhadap aturan waktu. Hal ini menunjukkan bahwa karyawan selalu selalu datang dan pulang sesuai dengan jam yang sudah ditetapkan oleh perusahaan. Pada saat jam kerja karyawan juga tidak pernah meninggalkan tempat kerja selama jam kerja jika tidak mendapatkan izin dari atasan.

Hasil tersebut menunjukkan disiplin waktu merupakan hal yang paling penting untuk dilakukan oleh seluruh karyawan. Dengan demikian karyawan akan fokus menyelesaikan pekerjaannya. Jika perusahaan tidak menerapkan sikap disiplin kerja khususnya disiplin waktu akan menyebabkan pekerjaan menjadi terbengkalai. Mulai dari seringnya terlambat datang, hingga pekerjaan selalu selesai di luar batas deadline. Jika sudah seperti ini, pekerjaan akan nampak tidak profesional. Berbeda halnya jika memiliki sikap disiplin waktu, membuat waktu bekerja akan lebih efisien. Dengan adanya disiplin waktu karyawan dapat 
menyelesaikan pekerjaan lebih banyak dari pada target yang diberikan. Dengan demikian hal tersebut dapat memberikan dampak yang baik terhadap peningkatan kinerja karyawan itu sendiri dan kinerja perusahaan.

PT. PLN yang merupakan Badan Usaha Milik Negara (BUMN) memang menerapkan aturan-aturan dan disiplin kerja yang ketat kepada karyawannya khususnya kehadiran. Sistem absensi dengan menggunakan finger print adalah salah satu metode absensi yang digunakan sehingga kehadiran dan keterlanbatan akan mudah terekam. Konsekuensi dari pelanggaran disiplin waktu adalah pemotongan gaji sampai dengan PHK. Hal inilah yang memberikan pengaruh yang baik terhadap kinerja karyawan.

Kedisiplinan merupakan salah satu fungsi operasional manajemen sdm yang penting karena semakin baik kedisiplinan karyawan, maka semakin baik pula kinerja karyawan. Hasil Penelitian ini sejala dengan penelitian yang dilakukan beberapa penelitian terdahulu yang menunjukkan bahwa disiplin kerja memberikan pengaruh yang positif dan signifikan terhadap kinerja karyawan. Hal ini mendorong gairah kerja, semangat kerja dan terwujudnya tujuan perusahaan dan pegawainya.

\section{Pengaruh Motivasi}

(X2)

\section{Terhadap Kinerja (Y)}

Motivasi merupakan satu keinginan yang timbul dari diri seseorang atau individu karena terinspirasi, terdorong untuk melakukan aktivitas dengan senang hati atau ikhlas tana ada paksaan sehingga aktivitas yang dilakukan tersebut mendapat hasil baik.

Berdasarkan hasil analisis regresi dan uji hipotesis menunjukkan bahwa variabel Motivasi memberikan pengaruh positif terhadap kinerja karyawan pada PT. PLN (Persero) UP3J Sulawesi Selatan. Namun Variabel Motivasi tidak memberikan pengaruh yang signifikan. Variabel ini merupakan variabel yang memberikan pengaruh paling kecil diantara variabel bebas lainnya.

Jika melihat gaji sebagai indikator motivasi pada perusahaan PT. PLN (Persero) UP3J Sulawesi Selatan sebagai perusahaan BUMN. Gaji karyawan rata-rata berada pada rentang 6 juta- 8 juta rupiah. Jumlah ini menunjukkan bahwa gaji bukan lagi merupakan faktor untama yang memberikan pengaruh paling besar terhadap motivasi kerja. Berdasarkan jawaban responden pertanyaan nomor 1 yang menyangkut tentang bekerja demi mendapatkan gaji hanya memberikan indeks sebesar $61 \%$. Motivasi khususnya melalui pemberian gaji merupakan hal yang mutlak dan merupakan hak dasar seorang karyawan yang harus dipenuhi oleh perusahaan sebagai salah satu faktor yang meningkatkan kinerja. Namun motivasi melalui pemberian gaji adalah hal yang sudah seharusnya karyawan terima dengan kewajiban bekerja dengan baik 
untuk meningkatkan kinerja perusahaan.

Tabel jawaban responden menunjukkan bahwa jawaban responden dengan skor total paling tinggi pada kuesioner Motivasi (X2) adalah penyataan nomor 7 dengan indeks sebesar $85 \%$. Pernyataan ini adalah Saya bekerja karena ingin kesempatan promosi jabatan atau kenaikan pangkat. Salah satu motivasi seseorang bekerja pada suatu organisasi atau perusahaan adalah adanya kesempatan untuk mengembangkan potensi-potensi yang ada dalam diri. Hal ini sudah menjadi salah satu sifat dasar dari manusia pada umumnya untuk bisa menjadi lebih baik, karena itulah mereka memotivasi dirinya untuk kemajuan dalam hidupnya.

Kebutuhan akan kekuasaan adalah kebutuhan untuk membuat orang lain berperilaku dalam suatu cara dimana orang-orang itu tanpa dipaksa tidak akan berperilaku demikian atau suatu bentuk ekspresi dari individu untuk mengendalikan dan memengaruhi orang lain. Hal ini menunjukkan bahwa karyawan akan bekerja dengan baik untuk mendapatkan kenaikan jabatan. Semakin tinggi jabatan yang didapatkan tetntunya akan meningkatkan pendapatan dan harga diri karyawan tersebut. Hasil tersebut merupakan faktor yang memberikan pengaruh positif terhadap kinerja karyawan.

Namun promosi jabatan atau kenaikan pangkat merupakan hal yang sangat kecil kemungkinan untuk didapatkan oleh seluruh karyawan. Karena, semakin tinggi posisi atau jabatan dalam organisasi, semakin kecil pula jumlah formasi yang dibutuhkan. Disamping jumlah formasi sedikit promosi jabatan juga didasari oleh banyak faktor bukan hanya melihat dari kinerja saja. Faktor-faktor seperti pengalaman, tingkat pendidikan, Tanggung Jawab, Kejujuran, Loyalitas merupakan faktor yang tidak semua dimiliki oleh karyawan. Hal inilah yang memberikan pengaruh Motivasi yang tidak signifikan terhadap kinerja karyawan.

Faktor lain yang memberikan pengaruh motivasi tidak signifikan adalah kekompakan para karyawan. Berdasarkan jawaban responden menunjukkan indeks paling rendah pada kuesioner motivasi adalah pernyataan nomor 5. Dengan kurangnya kekompakan maka akan menyebabkan karyawan kurang menyesuaikan diri terhadap lingkungan kerjanya khususnya pada rekan kerja. Beberapa akibat yang timbul dari kurang kompaknya karyawan dalam bekerja dapat menimbulkan perbedaan pendapat, kurangnya kepercayaan diri, dan akan berharap kepada orang lain dalam menyelesaikan tugas sehingga hal tersebut dapat mengurangi motivasi kerja karyawan.

Meskipun pengaruhnya tidak signifikan, hasil penelitian bahwa motivasi berpengaruh positif sesuai dengan pendapat Robbins (2015) yang menyatakan bahwa motivasi adalah proses yang menunjukkan intensitas individu, arah, dan ketekunan dari upaya menuju pencapaian tujuan. Dari penjelasan diatas dapat 
disimpulkan bahwa dengan adanya motivasi dan karyawan tersebut termotivasi untuk bekerja, membuat ia lebih berusaha dan tekun dalam bekerja untuk mencapai tujuan baik itu untuk pribadi atau organisasi. Jika karyawan telah terdorong untuk bekerja tentunya hal itu akan membuat kinerja karyawan semakin baik, karena perilaku seseorang cenderung berorientasi pada tujuan dan didorong oleh keinginan untuk mencapai tujuan.

3. Pengaruh Gaya Kepemimpinan (X3) Terhadap Kinerja (Y)

Gaya kepemimpinan

merupakan aspek penting untuk mencapai dan meningkatkan keberhasilan kepemimpinan seseorang dalam suatu organisasi. Gaya kepemimpinan adalah pola sikap dan perilaku yang ditampilkan dalam proses mempengaruhi orang lain.

Berdasarkan hasil analisis regresi dan uji hipotesis menunjukkan bahwa variabel Gaya Kepemimpinan memberikan pengaruh yang positif dan signifikan terhadap kinerja karyawan pada PT. PLN (Persero) Unit Pelaksana Proyek Pembangkit dan Jaringan Sulawesi Selatan.

Tabel jawaban responden menunjukkan bahwa jawaban responden dengan skor total paling tinggi pada kuesioner Gaya Kepemimpinan (X3) adalah penyataan nomor 7 dengan indeks sebesar 91,11\%. Pernyataan ini adalah Pimpinan turut berperan aktif dalam meningkatkan produktifitas perusahaan.
Berdasarkan hasil tersebut dapat dinyatakan bahwa pimpinan PT. PLN (Persero) Unit Pelaksana Proyek Pembangkit dan Jaringan Sulawesi Selatan menerapkan gaya Kepemimpinan Direktif, kepemimpinan ini membuat bawahan agar tahu apa yang diharapkan pimpinan dari mereka, menjadwalkan kerja untuk dilakukan, dan dibimbing khusus mengenai bagaimana menyelesaikan tugas. Dengan turut sertanya pimpinan untuk turut berperan aktif dalam meningkatkan produktifitas akan memberikan semangat kepada karyawan untuk aktif pula dalam menyelesaikan pekerjaan. Dengan dukungan pimpinan ini tentenya dapat mendorong peningkatan kinerja pada kantor tersebut.

Pimpinan yang memberikan pengarahan dimana pimpinan perusahaan memberikan penjelasan pada karyawannya, agar karyawan dapat menyelesaikan pekerjaan dengan baik, dan pemimpin mempengaruhi karyawan atau anggotanya untuk mengikuti keinginannya dengan menggunakan keahliannya atau kekuasaan jabatan secara efektif dan sesuai dengan aturan yang ada demi kepentingan perusahaan.

Dengan gaya kepemimpinan yang diterapkan ini kompetensi, pengalaman dan pengetahuan bawahan akan meningkat sehingga pekerjaan yang mereka lakukan akan lebih mudah sehingga berdampak positif terhadap peningkatan kinerja pada PT. PLN (Persero) UP3 dan Jaringan Sulawesi Selatan. 
Hasil penelitian ini sesuai dengan pendapat Kadarman (2001), yang berpendapat bahwa tugas seorang pemimpin ialah memberikan dorongan kepada bawahannya untuk mencapai suatu tujuan. Jadi memimpin suatu perusahaan atau organisasi pasti akan terlibat kemampuan seseorang untuk mempengaruhi orang lain atau bawahannya agar mereka melaksanakan tugas yang telah diberikan dengan baik. Dalam hal ini, motivasi menjadi aktifitas manajemen atau sesuatu yang dilakukan seorang pemimpin untuk mempengaruhi bawahannya atau anggotanya untuk bertindak secara terorganisir dengan cara tertentu agar dapat menghasilkan kinerja yang efektif.

\section{PENUTUP}

\section{Kesimpulan}

Berdasarkan hasil penelitian dan pembahasan di atas dapat diambil kesimpulan sebagai berikut:

Variabel disiplin kerja memberikan pengaruh yang signifikan terhadap kinerja karyawan, begitupun variabel motivasi memberikan pengaruh yang positif namun tidak signifikan terhadap kinerja karyawan dan variabel gaya kepemimpinan memberikan pengaruh yang baik dan signifikan terhadap Kinerja Karyawan pada PT. PLN (Persero) UP3 dan Jaringan Sulawesi Selatan. Secara simultan disipilin, motivasi dan gaya kepemimpinan berpengaruh positif dan signifikan terhadap kinerja karyawan PT. PLN (Persero) UP3 dan Jaringan Sulawesi Selatan.

\section{Saran}

Adapun saran yang dapat peneliti berikan kepada pihak-pihak yang berkepentingan dari penelitian ini adalah :

Memberikan arahan yang mampu mendorong kedisiplinan karyawan. Apabila karyawan sadar akan tugas dan tanggung jawabnya maka sangat berpengaruh terhadap kinerjanya sendiri. Semakin tinggi kesadaran karyawan akan menimbulkan kegairahan untuk bekerja sehingga menciptakan kinerja yang lebih baik. Memberikan kesempatan promosi jabatan kepada karyawan yang memenuhi syarat. Dengan adanya kesempatan promosi jabatan akan memberikan motivasi yang baik kepada karyawan sehingga karyawan akan bersemangat dalam mencapai kinerja. Diharapkan pimpinan dapat terus memberikan pengarahan kepada karyawan dalam bekerja. Dengan adanya pengarahan dari pimpinan, akan meningkatkan kemampuan karyawan dalam menyelesaikan tugas dengan baik.

\section{DAFTAR PUSTAKA}

Agustuti Handayani (2010) “Analisis Pengaruh Gaya Kepemimpinan dan Motivasi Kerja Terhadap Kinerja Pegawai Pada Dinas Tenaga Kerja Provinsi Lampung," Jurnal Ilmiah Adminstrasi Publik dan Pembangunan, Vol. 1

Fahmi, I. (2013) Manajemen Kinerja, Teori dan Aplikasinya. Bandung: Alfabeta.

Franklin, A. L., \& Pagan, J. F. (2006) Organization Culture as an Explanation for Employee Discipline Practices. Review of Public Personel Adminstration, 
$26(1), 52-73$

Ghalih (2013) Disiplin Keja Pegawai. Jakarta. Jakarta: PT. Raja Gravindo Persada.

Helmi, A. F. (1996) Disiplin Kerja. Buletin Psikologi, Tahun IV, No. 2, 32 - 42

Kadarman (2001) Sistem Pengawasan Manajemen. Jakarta: Pustaka Quantum.

Liden, R. C., Kraimer, M. L., \& Sandy, J. (2001) Managing Individual Performance in Work Groups. Journal Human Resource Management, 40 (1), $67-72$

Mulyadi, V. R. (2011) Kepemimpinan dan Perilaku Organisasi. Jakarta: PT. Raja Gravindo Persada.

Moeheriono, T. (2012) Moeheriono, T. Jakarta: PT. Raja Gravindo Persada.

Nawawi (2011) Manajemen Sumber Daya Manusia: Untuk Bisnis Yang Kompetetif. Yogyakarta: Universitas Gajah Mada Press.

Robbins, S. P. (2015) Perilaku Organisasi. Jakarta: Salemba Empat.

Riani, A. L. (2013) Manajemen
Sumber Daya Manusia Masa Kini. Yogyakarta: PT. Graha Ilmu.

Rivai, V. dkk (2014) Kepemimpinan dan Perilaku Organisasi. Jakarta: PT. Raja Gravindo Persada.

Setiyawan (2006) "Pengaruh Displin Kerja Karyawan Dan Budaya Kerja Terhadap Kinerha Di Divisi Radiologi RSUP Dokter Kariadi Semarang," Jrbi, Vol. 2 No, hal. 181-198.

Shadere, O. A. (2009) "Influence of Work Motivation, Leadership Effectiveness and time Management on Employees". Performance in Some Selected Industries in Ibadan, Oyo, State, Nigeria". European Journal of Economics. 1 (16), 817

Torang, S. (2012) Metode Riset Struktur \& Perilaku Organisasi. Bandung: Alfabeta. Usman, H. (2014) Manajemen, Teori, Praktek dan Riset Pendidikan. Jakarta: Bumi Aksara.

Widodo \& Sunarso (2009) Jurnal Manajemen Sumber Daya Manusia, Vol. 3 No. 1. 